\title{
Economic Globalization and a Nuclear Renaissance
}

\author{
TW Wood \\ WL Johnson \\ BM Parker
}

October 2001

Prepared for the U.S. Department of Energy under Contract DE-AC06-76RLO 1830 


\title{
DISCLAIMER
}

This report was prepared as an account of work sponsored by an agency of the United States Government. Neither the United States Government nor any agency thereof, nor Battelle Memorial Institute, nor any of their employees, makes any warranty, express or implied, or assumes any legal liability or responsibility for the accuracy, completeness, or usefulness of any information, apparatus, product, or process disclosed, or represents that its use would not infringe privately owned rights. Reference herein to any specific commercial product, process, or service by trade name, trademark, manufacturer, or otherwise does not necessarily constitute or imply its endorsement, recommendation, or favoring by the United States Government or any agency thereof, or Battelle Memorial Institute. The views and opinions of authors expressed herein do not necessarily state or reflect those of the United States Government or any agency thereof.

\author{
PACIFIC NORTHWEST NATIONAL LABORATORY \\ operated by \\ BATTELLE \\ for the \\ UNITED STATES DEPARTMENT OF ENERGY \\ under Contract DE-ACO6-76RLO183O
}

Printed in the United States of America

Available to DOE and DOE contractors from the

Office of Scientific and Technical Information,

P.O. Box 62, Oak Ridge, TN 37831-0062;

ph: (865) 576-8401

fax: (865) 576-5728

email: reports@adonis.osti.gov

Available to the public from the National Technical Information Service, U.S. Department of Commerce, 5285 Port Royal Rd., Springfield, VA 22161

ph: (800) 553-6847

fax: (703) 605-6900

email: orders@ntis.fedworld.gov

online ordering: http://www.ntis.gov/ordering.htm

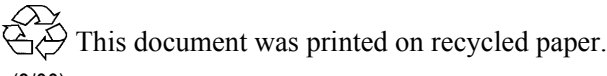

$(8 / 00)$ 


\title{
Economic Globalization and a Nuclear Renaissance
}

\author{
TW Wood \\ WL Johnson \\ BM Parker
}

October 2001

Prepared for

the U.S. Department of Energy

under Contract DE-AC06-76RL01830

Pacific Northwest National Laboratory

Richland, WA 99352 


\section{Summary}

The phenomenon of globalization has become increasingly well recognized, documented, and analyzed in the last several years. Globalization, the integration of markets and intra-firm competition on a worldwide basis, involves complex behavioral and mindset changes within a firm that facilitate global competition. The changes revolve around efficient information flow and rapid deployment of technology. The objective of this report is to examine the probable characteristics of a global nuclear renaissance and its broad implications for industry structure and export control relative to nuclear technology. The question of how a modern renaissance would affect the trend toward globalization of the nuclear industry is addressed.

This study concludes that modest improvements in the costs of nuclear power plants, coupled with their recent record of substantially improved operational performance, could result in a true "nuclear renaissance" within the next several decades. The improved economics required for this would come from "generation III+" and early "generation IV" plants," which substantially simplify plant safety and operation and are capable of being built in a much shorter time than the light water reactors now in service. Given the relative economics of nuclear and fossil units, a 20 to 30 percent decrease in unit cost could easily increase worldwide nuclear plant construction activity tenfold over current levels. The fact that licensing new designs and generating investor confidence will not happen precipitously means such a renaissance will take at least several years (probably a decade or two) to develop.

Such a renaissance in nuclear power would greatly expand the volume of international nuclear technology trade over current levels. Some of the most promising new reactor designs are being developed by broad international consortia, and all would be marketed on a worldwide basis. This scenario would not reverse (and might reinforce) the trend toward globalization of the nuclear industry because only a few viable reactor designs would emerge, even in an aggressive scenario, and the cost-effectiveness required for selling these designs would be best achieved in a global nuclear technology firm. 


\section{Table of Contents}

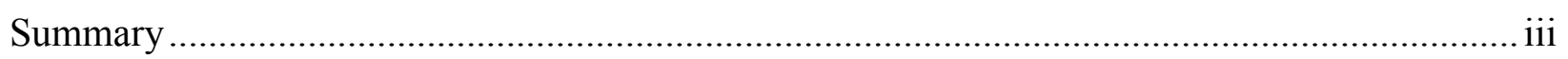

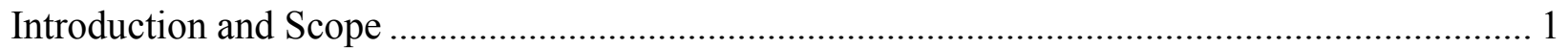

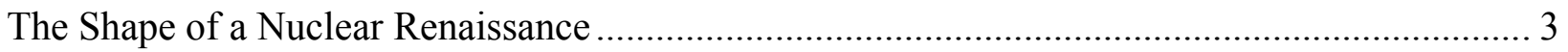

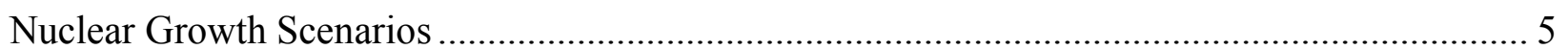

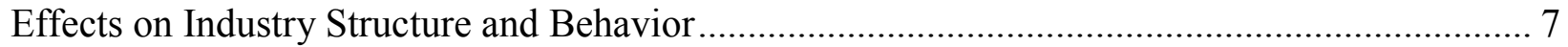

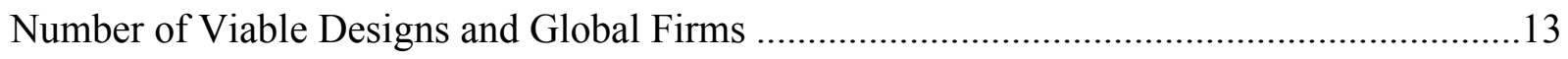

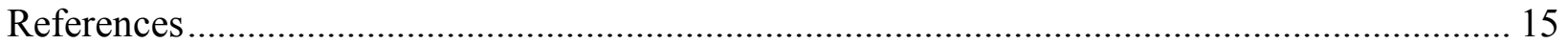

\section{Figures}

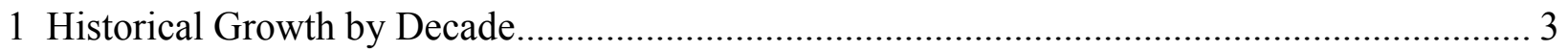

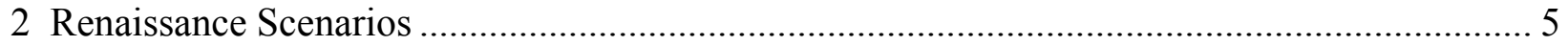

3 Renaissance Scenarios Including Renaissance Reference Case ……................................... 6

4 Evolution of Power Reactor Designs ................................................................................ 9

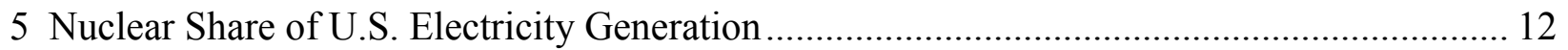

\section{Tables}

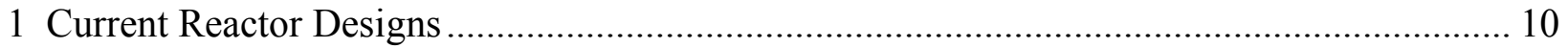

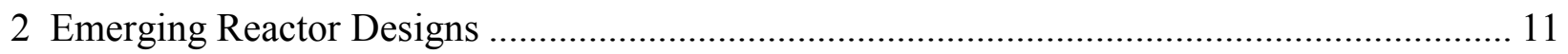




\section{Introduction and Scope}

The phenomenon of globalization has become increasingly well recognized, documented, and analyzed in the last several years. Briefly, globalization is the integration of markets and intrafirm competitive behavior on a worldwide basis (Wolf 2000). Behind this simple definition is a complex set of behavioral and mindset changes within a firm that facilitate global competition. These changes revolve around the central themes of efficient information flow and rapid deployment of technology.

While the globalization trend is now virtually ubiquitous in technology industries, it has been most fully realized in electronics and communications. It is also a fact of life in the nuclear technology sector. A previous study, Economic Globalization and Nuclear Technology Supply, An Exploratory Investigation (Wood et al. 2000), examines and documents this trend in the nuclear technology industry.

While the previous study concluded that only one (Siemens) of four large firms studied displayed all of the earmarks of a global firm, a series of acquisitions followed the publication of that report almost immediately, completing the globalization process for a large segment of the nuclear industry. These included the purchase of the nuclear assets of Siemens by Framatome and the formation of Framatome Advanced Nuclear Power (ANP). At about the same time, British Nuclear Fuels Limited (BNFL) purchased all of the nuclear assets of Westinghouse (with the exception of the naval reactor division at Bettis Labs) and announced its global stature.

A parallel trend during the last two years has been a rebirth of serious interest in nuclear power. Economic, environmental, and political factors are now aligning to drive a "renaissance" in the use of nuclear power for electrical energy production. Based on economic factors in electrical energy markets and the fact that the current fleet of nuclear plants are rapidly approaching the end of their initial license periods, a strong economic incentive exists for new plant orders during the next 10 to 15 years.

The momentum for a nuclear renaissance continues to look increasingly strong. [See Lawrence (2000) for an overview or NEA (2000) for a more detailed treatment.] In addition to several industry analyses and trade press articles, the prospect of a renaissance is now featured widely in the popular press and is being formally assessed as an element of the White House Energy Strategy (Holt and Behrens 2001). There are, however, significant barriers to this prospect. These include materials longevity and other life-extension issues for existing plants, construction timetables and costs for currently licensed but not-yet-built reactor designs, both cost and dem- 
onstrated safety for emerging designs, spent-fuel management and disposal for all reactors, and public acceptance for any new reactor construction.

The objective of this report is to examine the probable characteristics of a nuclear renaissance in a qualitative manner, and its broad implications for industry structure and export control relative to nuclear technology. In particular, the question of how a modern renaissance would affect the trend toward globalization of the nuclear industry is addressed. 


\section{The Shape of a Nuclear Renaissance}

The term "nuclear renaissance" has come in to broad use without an accepted, explicit, quantitative definition. Our definition is that of a significant shift in the relative attractiveness of new nuclear plants vis-à-vis fossil fuel power sources. A "significant" shift is one that makes generation of new plants economically viable. It matters not whether this shift is created by cost increases in fossil fuels, imposition of a carbon tax, or a generation of more cost-effective nuclear designs. The important feature that all of these scenarios share is that more nuclear plants would be built than would otherwise be the case.

A useful point of departure for consideration of possible nuclear futures is found in nuclear power's history for the past three decades. Figure 1 illustrates the growth in worldwide nuclear energy production. The period 1970-1980 saw very rapid growth-a total of 700\%, or about $22 \%$ per year at a compounded rate. Even the 1980 s, well after the last plant had been ordered in the U.S., saw growth of over $160 \%$ as plants were completed and capacity factors grew rapidly. The last decade has seen modest growth, composed primarily of plant completions outside the U.S. and continued but slower growth in capacity factors at previously completed plants.

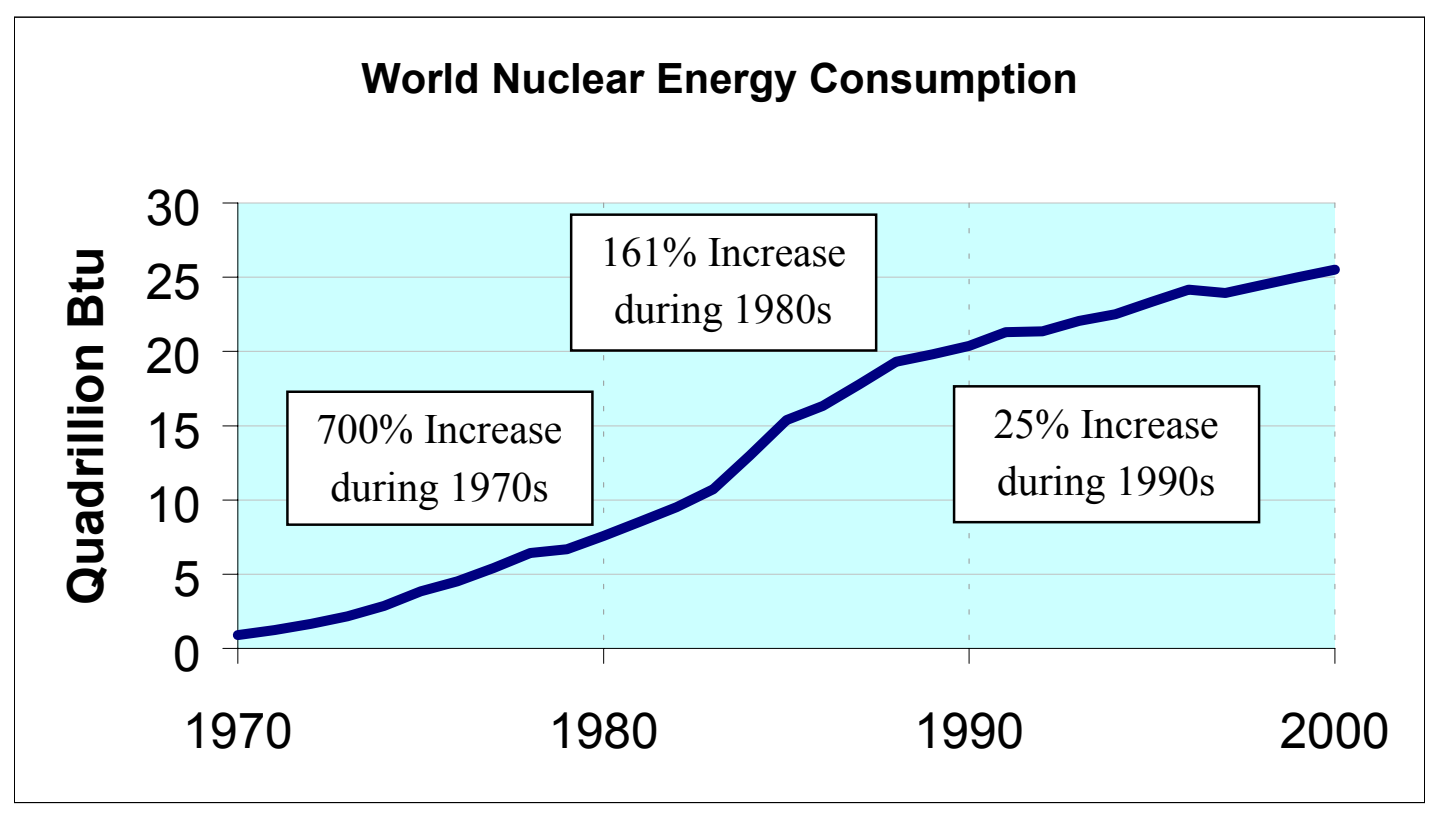

Figure 1. Historical Growth by Decade 
This growth history holds some important lessons in terms of a nuclear renaissance. First, it is quite possible, from an industry capacity point of view, to return to something like the absolute growth rate of the 1970s, when hundreds of plants were under construction. (It is very doubtful that the relative growth rate of $700 \%$ could be achieved starting from a base of 400 plants worldwide.) Second, there is significant inertia in the plant construction industry due to the length of plant construction timetables. Even if a nuclear renaissance is fully realized, it will not happen overnight. Third, even a return to the absolute growth rate of the 1970 s would represent a very significant increase in the current level of international nuclear technology trade. There are now only ten plants under active construction worldwide (Nuclear News 2000). 


\section{Nuclear Growth Scenarios}

While there is growing consensus that a nuclear renaissance may be in prospect, the best-known formal energy forecasts fail to include scenarios that meet the definition above. Figure 2 depicts three of the popular current forecasts - the Energy Information Administration (EIA) "low" and "reference" cases and the Nuclear Energy Agency (NEA) "high" case. The EIA reference case predicts an essentially constant absolute nuclear power capacity of around $350 \mathrm{GWe}$ for the next two decades. Against the background of significant growth in electrical energy demand, this represents a deterioration of the share of electrical energy generated by nuclear from $16 \%$ to $9 \%$ worldwide in the next two decades — certainly not a nuclear renaissance.

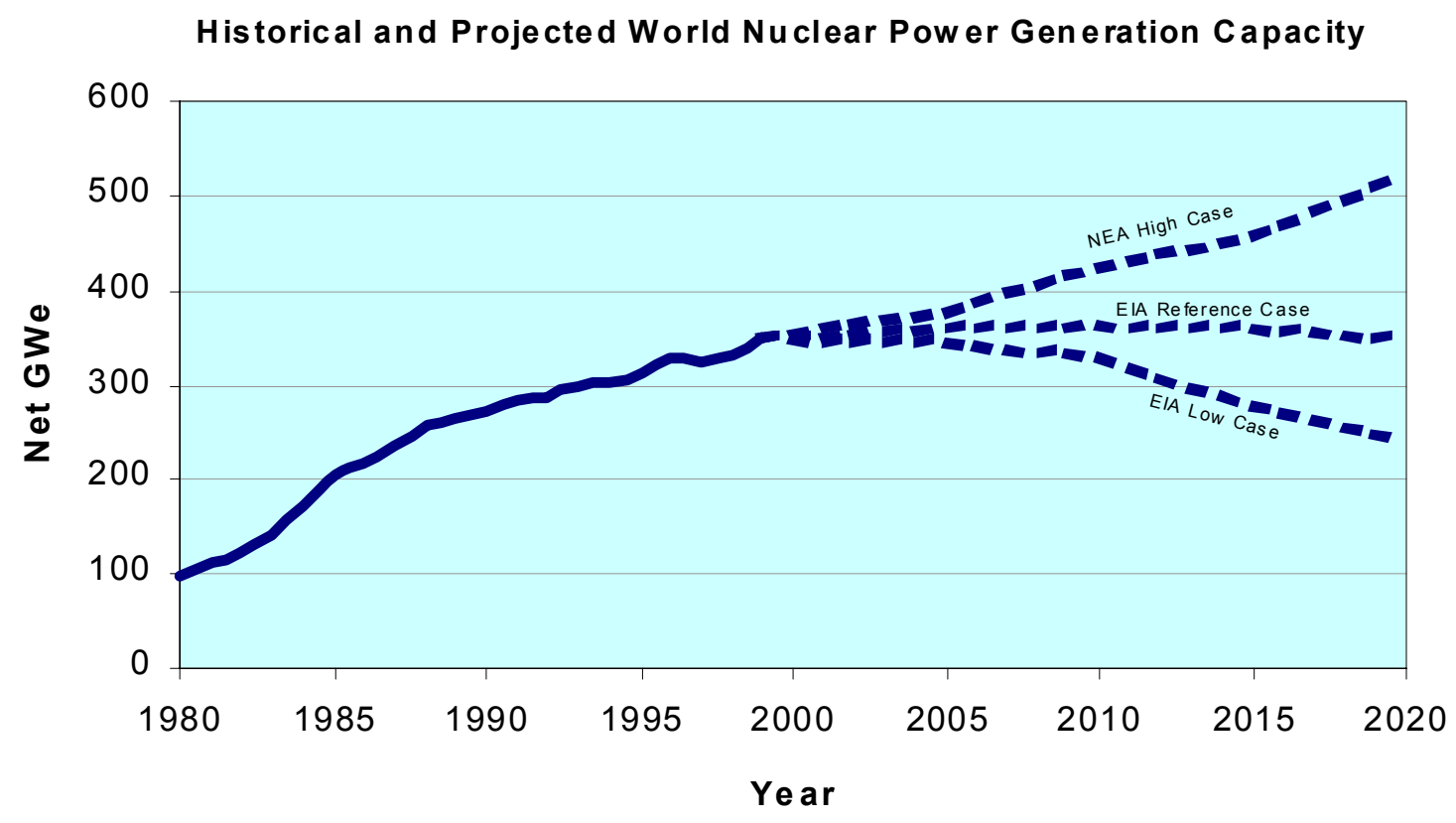

Figure 2. Renaissance Scenarios

Even the NEA [who announced that "the renaissance is at hand" (NEA 2000)] predicts a loss in the share of electrical energy generated by nuclear in their "high" case. This is not to critique the validity of the forecasts or their assumptions but simply to underscore that a true renaissance, in which nuclear power became significantly more cost-effective, could involve growth rates much greater than envisioned in the current standard cases from accepted models.

To gain a simple reference point for the possible magnitude of this growth, we postulated a "renaissance reference" scenario in which the world share of electrical energy generated by nuclear increased from $16 \%$ (currently) to $20 \%$ by 2020 . Using the EIA's (reference case) total 
electrical energy figure of 22,300 TWh for 2020 and an assumption of constant productivity (plant capacity factor), this results in $760 \mathrm{GWe}$, more than double the current $351 \mathrm{GWe}$. At current plant sizes, this represents 410 new plants. This underscores the knife-edge nature of the nuclear power generation market - a modest increase in the share of the electrical market results in a very significant change in the number of plants under construction (and thus the level of nuclear technology sales). Assuming a plant construction time of five years, this forecast would result in an average of 100 plants under construction at any given time - an order of magnitude greater than current levels.

Once again, this is a hypothetical case, but it represents a modest realization of a nuclear renaissance as we have defined it. This case is plotted against the three standard scenarios in Figure 3.

\section{Historical and Projected World Nuclear Power Generation Capacity}

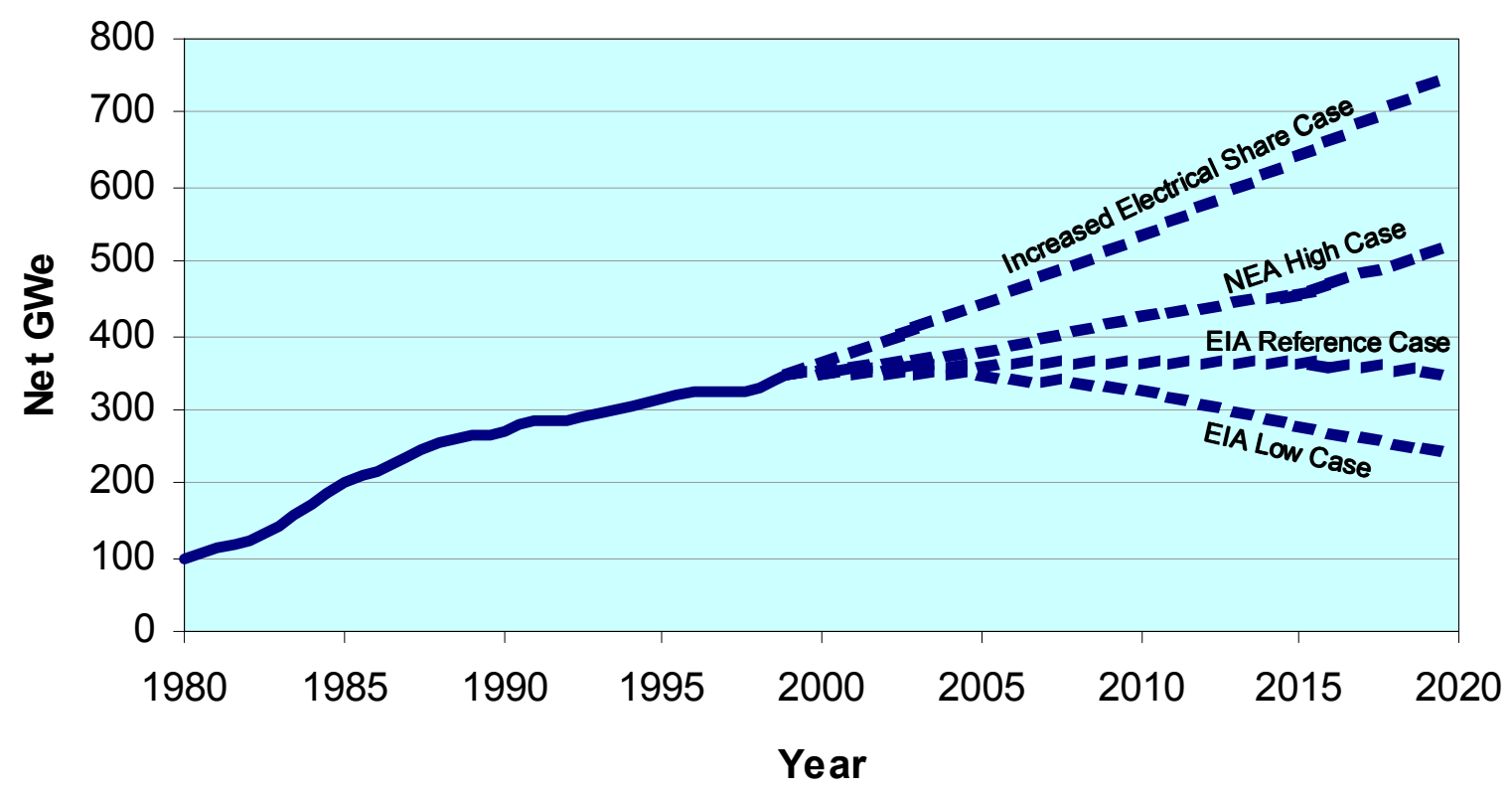

Figure 3. Renaissance Scenarios Including Renaissance Reference Case 


\section{Effects on Industry Structure and Behavior}

This paper began from a simple question: Would a nuclear renaissance result in the reversal of the globalization trend we found in our 2000 study? $^{(a)}$ This question was generalized to, What would be the likely effects of a nuclear renaissance on the nuclear technology supply sector, both in terms of industry structure and competitive behavior? We address this question, first on grounds of economic theory, and second on the level of specific reactor designs and their probable market penetration.

From a theoretical perspective, there is no reason to expect a dramatic change in the volume of nuclear technology business to reverse the process of globalization. In fact, the same factors of reducing cost and streamlining the technology delivery process are causative for both phenomena. The basic reason that acquisitions and large-scale consolidation have been so widespread and rapid is that cost-effectiveness has been a prerequisite for survival in a limited global market. It is not true, however, that a growing market will remove the need for cost-effectiveness; in fact, it is the cost advantage (relative to other power sources) that would drive the market growth. Globalized firms are in the best position to deliver this cost advantage.

The second theoretical consideration derives from the definition of globalization as the integration of markets. One important aspect of this integration is the lack of systematic product differentiation among geographic markets. While some elements of nuclear technology (notably uranium enrichment and fuel) have long been delivered in integrated worldwide markets, reactor designs themselves were somewhat geographically diverse during the first decades of the industry. At present, there is a standard set of designs that is emerging as potentially competitive on a worldwide basis. Because developing and licensing a new reactor design represents a substantial investment, these are strong incentives to market any viable design on a global basis.

The mechanics of the nuclear business dictate that the most important determinant of industry structure will be number of reactor designs that are competitive. In order to examine how many global firms will be viable in a nuclear renaissance, it is necessary to understand how many designs are viable. We investigated this question based on published information for current and emerging designs.

Figure 4 presents a general scheme describing the evolution of power reactor designs between 1950 and 2030. The "generations" shown in this scheme are generally accepted industry classi-

(a) This question was posed by Adam Sheinman during a review of our work for DOE NN-43. 
fications as defined by the U.S. Department of Energy (NERAC 2001). The current state-of-theart in power reactor technology is represented by Generation III designs. These are light water reactors that incorporate some passive safety features and have been licensed for construction and commercial operation. Table 1 gives some design and cost parameters for these designs as well as the older Generation II designs.

Generation III designs are noteworthy because their current construction cost is in the range of $\$ 1300$ to $\$ 1500$ per kW of electrical capacity. To be economic in today's electrical energy market, a power plant must be very close to $\$ 1000$ per $\mathrm{kWh}$ if natural gas is readily available. Thus current generation nuclear plants are limited to a market niche in which natural gas is not readily available; i.e., they are not globally competitive electrical energy resources.

The "emerging" reactor designs in Figure 4 are expected to be more economic. Table 2 gives summary design and operational information on emerging designs. Both Generation III+ and Generation IV designs are projected to come in at or very close to the $\$ 1000$ per $\mathrm{kW}$ price point. Thus the evolution of global nuclear industry structure depends to a large extent on how fast these new designs are realized and to what extent their actual costs reflect these estimates.

A recent paper (Reis 2001) addresses this question using "Power Choice" (a systems dynamics model). This paper modeled the probable U.S. market penetration for Generation II through Generation IV plants under a variety of timing and carbon credit scenarios. Figure 5 (reproduced from Reis) shows U.S. market penetration (measured as share of electrical energy generated) as a function of time for five scenarios.

The status quo in technology and energy regulation is represented as cases 1 and 3 in this figure. These cases show that without any carbon credit, neither Generation II nor III is economic, and the share of U.S. energy produced by nuclear goes from a current level of $20 \%$ to zero in twenty years. (The point at which the last plant ceases generation would of course also be sensitive to life extension, which is not assumed in this analysis.)

The effect of carbon taxes or carbon credits on nuclear (and other non-fossil) energy sources has been a frequent topic in the literature for about a decade. In general, carbon taxes on fossil sources or credits for non-fossil sources represent an attempt to adjust effective market prices to reflect the social costs of carbon emissions to the atmosphere. Recent studies estimate this cost to be in the range of hundreds of dollars per metric ton 


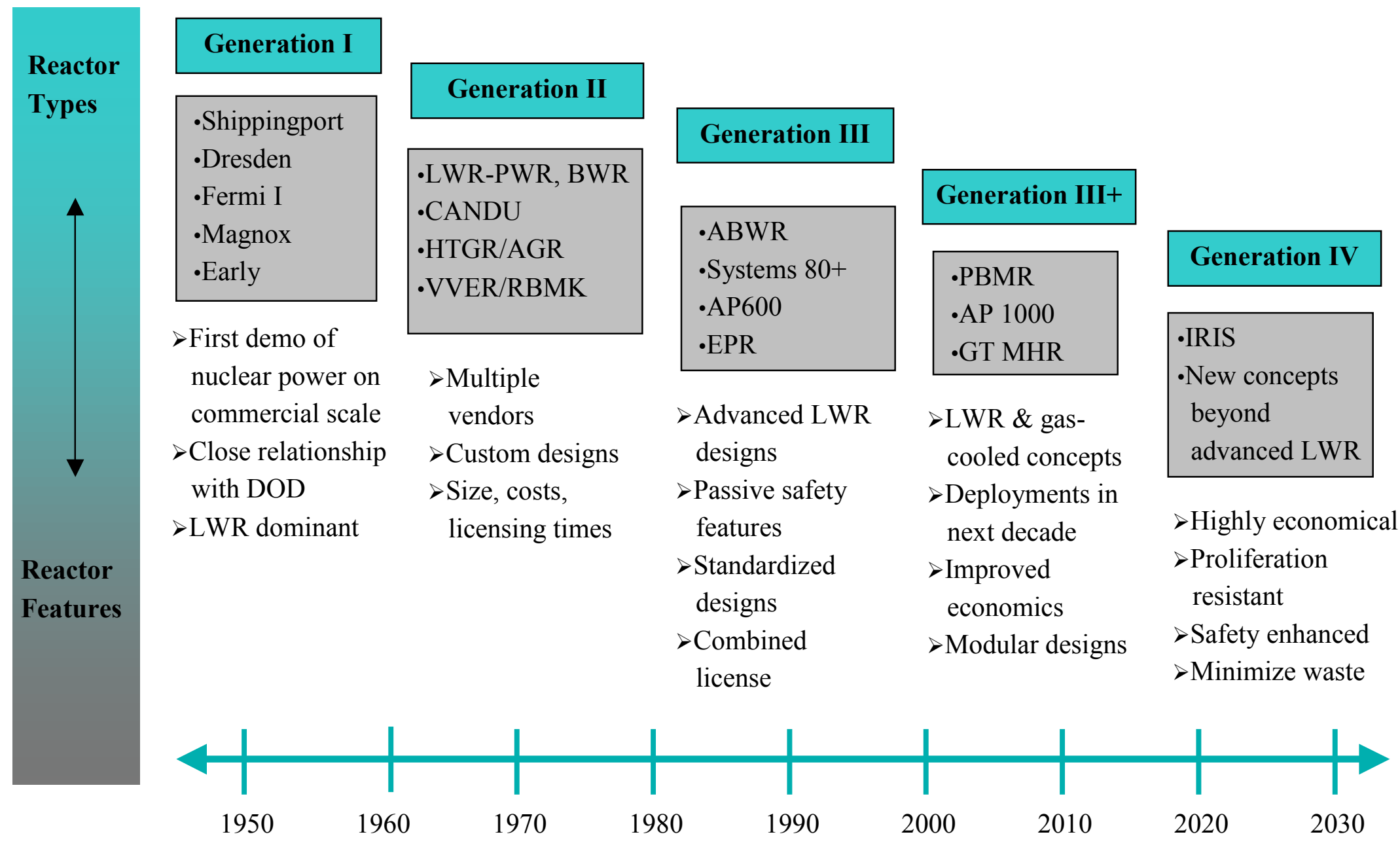

Figure 4. Evolution of Power Reactor Designs 
Table 1. Current Reactor Designs

Generation II Designs

\begin{tabular}{|l|l|l|l|l|}
\hline Reactor & Designer & Capacity/Cost & Features & Market \\
\hline $\begin{array}{l}\text { VVER } \\
\text { (several } \\
\text { designs) }\end{array}$ & & Varies by design & Soviet design & $\begin{array}{l}\text { Former Soviet Union, eastern bloc countries. Units } \\
\text { also planned or under construction in China, India, } \\
\text { Iran. }\end{array}$ \\
\hline $\begin{array}{l}\text { CANDU } \\
\text { (several } \\
\text { designs) }\end{array}$ & ACEL & Varies by design & $\begin{array}{l}\text { Uses natural Uranium, doesn't } \\
\text { require enrichment. }\end{array}$ & $\begin{array}{l}\text { Used mainly in Canada, two currently under } \\
\text { construction in China. Also used in India, Korea, } \\
\text { Pakistan, and Romania }\end{array}$ \\
\hline
\end{tabular}

\begin{tabular}{|c|c|c|c|c|}
\hline Reactor & Designer & Capacity/Cost & Features & Market \\
\hline AP-600 & $\begin{array}{l}\text { BFNL } \\
\text { (Westinghouse) }\end{array}$ & $\begin{array}{l}600 \mathrm{MWe} \\
\$ 1,520 / \mathrm{kW}\end{array}$ & $\begin{array}{l}\text { - Simplified construction and } \\
\text { operation ( } 3 \text { years to build) } \\
\text { - } 60 \text {-year plant life }\end{array}$ & NRC approved design. \\
\hline $\begin{array}{l}\text { System } \\
80+\end{array}$ & $\begin{array}{l}\text { Framatone } \\
(\mathrm{ABB})\end{array}$ & $\sim 1,300 \mathrm{MWe}$ & $\begin{array}{l}\text { - Evolutionary Design } \\
\text { - Increased reliablility } \\
\text { - Simplified construction and } \\
\text { operation }\end{array}$ & $\begin{array}{l}8 \text { System } 80 \text { units in South Korea have already } \\
\text { incorporated several } 80+\text { features into it's designs } \\
\text { for their Next Generation Reactor. Being marketed } \\
\text { in China. }\end{array}$ \\
\hline ABWR & GE & $\begin{array}{l}\sim 1,350 \mathrm{MWe} \\
\$ 1,500 / \mathrm{kW}\end{array}$ & $\begin{array}{l}\text { - Simplified construction (target } \\
\text { of } 48 \text { months) } \\
\text { - More efficient, less waste } \\
\end{array}$ & $\begin{array}{l}\text { Commercial operation in Japan since 1996-97. Two } \\
\text { currently under construction in Taiwan. }\end{array}$ \\
\hline EPR & Framatome & $\begin{array}{l}1,750 \mathrm{MWe} \\
\$ 1,300 / \mathrm{kW}\end{array}$ & $\begin{array}{l}\text { - Evolutionary Design } \\
\text { - High fuel efficiency }\end{array}$ & $\begin{array}{l}\text { Confirmed as future French standard. Jointly } \\
\text { developed by France and Germany. Licensed in } \\
\text { UK. }\end{array}$ \\
\hline
\end{tabular}


Table 2. Emerging Reactor Designs

Generation III+ Designs
\begin{tabular}{|l|l|l|l|l|}
\hline Reactor & Designer & Capacity & Features & Market \\
\hline PBMR & BNFL (Eskom) & $\begin{array}{l}110 \mathrm{MWe} \\
\sim \$ 1,000 / \mathrm{kW}\end{array}$ & $\begin{array}{l}\text { - Modular plant, low cost. } \\
\text { - Direct cycle gas turbine } \\
\text { - Ceramic coated fuel }\end{array}$ & $\begin{array}{l}\text { Prototype construction 2001-2002 in South Africa } \\
\text { using private money. Modular design, low } \\
\text { maintenance make it attractive to developing } \\
\text { countries. }\end{array}$ \\
\hline AP-1000 & $\begin{array}{l}\text { BFNL } \\
\text { (Westinghouse) }\end{array}$ & $1,000 \mathrm{MWe}$ & $\begin{array}{l}\text { - Larger version of AP-600 } \\
\text { design } \\
\text { - Modular fabrication }\end{array}$ & $\begin{array}{l}\text { Will be submitted to NRC using AP-600 as base to } \\
\text { ease approval process, currently in pre-application } \\
\text { review with NRC. }\end{array}$ \\
\hline GT MHR & General Atomics & $\begin{array}{l}250-285 \mathrm{MWe} \\
<\$ 1,000 / \mathrm{kW}\end{array}$ & $\begin{array}{l}\text { - Direct cycle gas turbine } \\
\text { - Operates at high temperature } \\
\text { - High fuel efficiency }\end{array}$ & $\begin{array}{l}\text { Multinational joint venture under development with } \\
\text { Russia. Commercial operation anticipated in 2010. } \\
\text { Initially will be used to burn ex-weapons plutonium } \\
\text { in Russia. }\end{array}$ \\
\hline
\end{tabular}

Generation IV Designs
\begin{tabular}{|l|l|l|l|l|}
\hline Reactor & Designer & Capacity & Features & Market \\
\hline IRIS & BFNL & $100-300 \mathrm{MWe}$ & - Minimum maintenance, \\
& (Westinghouse) & $\begin{array}{l}\text { 1,000- } \\
\$ 1,500 / \mathrm{kW}\end{array}$ & $\begin{array}{l}\text { - Long life fuel and unified } \\
\text { reactor core (entire reactor core } \\
\text { replaced during refuel) }\end{array}$ & deployment would be 2010-2015. \\
\hline
\end{tabular}






1 - Gen II nuclear and no carbon tax

4 - Gen III and \$100/tonne carbon

2 - Gen II and \$260/tonne carbon

3 - Gen III and no carbon tax

5 - Gen IV after 20 years and no carbon tax

Figure 5. Nuclear Share of U.S. Electricity Generation

This Reis study examined several scenarios in which carbon credits were assumed in conjunction with specific reactor generations. Scenario 2 assumes that Generation II reactors are eligible for a $\$ 260$ per ton carbon credit, and scenario 4 assumes that Generation III reactors are eligible for a $\$ 100$ per ton carbon credit.

Both of these cases represent true nuclear renaissance scenarios by our definition. Although the share of electricity produced by nuclear initially falls to about half its current value in both cases, the significant cost advantage eventually results in a rapidly increasing share, reaching between $50 \%$ and $60 \%$ in 100 years. This would (using an annual $1 \%$ electricity consumption growth rate and current reactor capacity factors) result in about 1,000 reactors on line in the U.S. in 2100 ten times the number now on line.

Scenario 5 in Figure 5 is the case in which Generation IV reactors are mature in 2020. These reactors by definition are competitive without carbon credits. This case predicts rebound from the point where no U.S. electricity is generated using modern plants to one in which about $65 \%$ 
of all electricity is nuclear, within the span of 80 years. This case might be termed the "nuclear resurrection" scenario. This case also results in about 1000 reactors on line.

While all of these scenarios are just modeling exercises, it is worth noting once again that plausible shifts in life-cycle reactor costs produce dramatic shifts in the electrical energy and nuclear technology sectors. The rate of plant construction in the U.S. is about 25 plants per year (assuming 1,000 MWe nominal reactors, with a 40 year design) in Reis's cases 2, 4, and 5.

Clearly, one important consideration in the likelihood and extent of a nuclear renaissance is the magnitude of carbon taxes or credits. Because this will be a national decision under current international treaties, the potential exists for distinct market segmentation based on uneven application of carbon credits or taxes. Our reading of the current U.S. energy policy at this juncture is that any significant national credits for nuclear plants are extremely unlikely. The U.S. stance on the Kyoto treaty would seem to make us less likely than the rest of the world to be an early adopter of a new generation of nuclear power plants. ${ }^{\text {(a) }}$

A final observation based on the Reis results is that the current U.S. DOE plan to target 2030 as the maturity date for Generation IV reactors may not be adequate to the market realities. Without carbon credits, this makes new reactors feasible just about the time the last existing reactors would shut down. Although the resurrection scenario results in dramatic numbers, it seems practically impossible in the real world.

\section{Number of Viable Designs and Global Firms}

Regarding the question of how many designers and global firms might be viable in a nuclear renaissance, our judgment is that probably 3 to 5 designs at most will be economic. The reason that a global (i.e., integrated) market does not settle on a single best design has something to do with market niches (i.e., lack of perfect integration) and something to do with timing. Some suppliers have clear advantages in some markets (Minatom in Russia, for example), and the ultimately more economic Generation III+ and IV reactors are not yet market-ready.

The question of how many viable global firms there will be is coupled to the number of designs. There will be a distinct advantage to firms offering new designs that have been demonstrated as

(a) We note that from an international trade perspective, this policy discriminates against those energy technologies where the U.S. is a net exporter (nuclear, solar, wind) and in favor of oil, where we are a net importer. 
safe and operationally reliable. While it is possible that a global nuclear services firm can exist without offering a new reactor, it is not likely, particularly in a market dominated by the volume of new construction typical in a nuclear renaissance. This would indicate that perhaps half a dozen globalized firms will constitute the core of the nuclear power industry for several decades. There is no reason to suspect that even rapid growth associated with a nuclear renaissance would change that. 


\section{References}

American Nuclear Society. November 2000. "Nuclear Power in the $21^{\text {st }}$ Century - Sixteen Perspectives on the Future of Nuclear Energy." Nuclear News.

Behr P. April 23, 2001. "Nuclear Power May Be Making a Comeback - Energy Crunch Helps Ease Industry's Image as Outcast." Washington Post.

Energy Information Administration. December 2000. Annual Energy Outlook 2001, Figure 73. U.S. Department of Energy, Washington, D.C.

Generation IV Roadmap NERAC Subcommittee. March 8, 2001. Technology Goals for Generation IV Nuclear Energy Systems.

Holt M and CE Behrens. January 12, 2001. IB88090: Nuclear Energy Policy. Congressional Research Service Issue Brief for Congress, Washington, D.C.

Lawrence MJ. 2001. "Nuclear Renaissance? Think Globally, Act Locally." Waste

Management 2001, Tucson, Arizona. PNNL-SA-34212, Pacific Northwest National Laboratory, Richland, Washington.

Nuclear Energy Institute. May 2000. Nuclear Energy: The Renaissance Revealed A Strategic Direction for the $21^{\text {st }}$ Century. Washington, D.C.

Reis VH and MP Crozat. January 2001. The Nuclear Strategies Project-Modeling Power Choice and Policy Options. Science Applications International Corp., McLean, Virginia.

Wolf CR. 2000. “Globalization, Meaning and Measurement.” Critical Review, Winter 2000.

Wood TW, JM Roop, LL Clark. October 2000. Economic Globalization and Nuclear Technology Supply, An Exploratory Investigation. PNNL 13370, Pacific Northwest National Laboratory, Richland, Washington. 


\section{Distribution}

No. of

Copies

\section{OFFSITE}

Steve Baker

Lockheed Martin Energy Systems

PO Box 2003 (MS: 7312)

Oak Ridge, TN 37831-7312

Maegon Barlow

U.S. Department of Energy

1000 Independence Ave SW

Washington, DC 20585-0440

Jeff Bedell

Los Alamos National Laboratory

PO Box 503(MS: B236 NIS-8)

Los Alamos, NM 87544

Al Boni

Savannah River Technology Center

Westinghouse Savannah River Co.

Bldg 735-A

Savannah River Site

Aiken, SC 29808

Joan Boudreau

Los Alamos National Laboratory

PO Box 503 MS: B230 NIS-8

Los Alamos, NM 87544

Gerald Bracken

U.S. Department of Energy, DOE-NN43

1000 Independence Ave S W

Washington, DC 20585-0440

Ken Cross

Lockheed Martin Energy Systems

PO Box 2003, MS: 7312

Oak Ridge, TN 37831-7312
No. of

Copies

7000 East Ave

PO Box 808

Livermore, CA 94550

Attn: Bill Domke, L-387

Mary Beth Ward, L-387

Don Finch

Savannah River Technology Center

Westinghouse Savannah River Co.

Savannah River Site, Bldg 735-A

Aiken, SC 29808

Ed Fox

U.S. Department of Energy, DOE-NN43

1000 Independence Ave SW

Washington, DC 20585-0440

Karen Wright

U.S. Department of Energy, DOE-NN43

1000 Independence Ave SW

Washington, DC 20585-0440

Rich Goorevich

U.S. Department of Energy, DOE-NN43

1000 Independence Ave SW

Washington, DC 20585-0440

John Gronager

Sandia National Laboratories

PO Box 5800 MS: 1217

Albuquerque, NM 87185

Brent Heilman

Argonne National Laboratory

9800 South Cass Avenue

TD 315 L215

Argonne, IL 60439 
PNNL-13685

No. of

Copies

Melissa Krupa

U.S. Department of Energy, DOE-NN43

1000 Independence Ave SW

Washington, DC 20585-0440

Todd Perry

U.S. Department of Energy, DOE-NN43

1000 Independence Ave SW

Washington, DC 20585-0440

Basil Picologlou

Argonne National Laboratory

TD 315 L215

9800 South Cass Avenue

Argonne, IL 60439

Adam Scheinman

U.S. Department of Energy, DOE-NN43

1000 Independence Ave SW

Washington, DC 20585-0440

Meggen Watt

U.S. Department of Energy, DOE-NN43

1000 Independence Ave SW

Washington, DC 20585-0440
No. of

Copies

Anatoli Welihozkiy

U.S. Department of Energy, DOE-NN43

1000 Independence Ave SW

Washington, DC 20585-0440

\section{ONSITE}

36 Pacific Northwest National Laboratory

E.L. Benjamin (5)

K8-41

W.C. Cliff

K8-46

R.A. Jensen

K8-41

W.L. Johnson (5)

K7-97

M.H. Killinger

K8-46

N.E. Maguire-Moffitt

K8-33

B.M. Parker (5)

K7-97

J.M. Roop

K8-17

C.E. Willingham

K8-41

T.W. Wood (10)

K7-94

Information Release (5) 